PUSTABIBLIA: Journal of Library and Information Science

ISSN 2549-3493 (Print); ISSN 2549-3868 (Online)

DOI: http://dx.doi.org/10.18326/pustabiblia.v5i2.225-244

SK Dirjen Risbang-Kemristekdikti No 23/E/KPT/2019 (Peringkat 4 SINTA)

\title{
Digitalisasi Grey Literature sebagai Strategi Pengembangan Koleksi pada Perpustakaan Fakultas Hukum Universitas Sriwijaya
}

\author{
Novita Vitriana, Triady Hermansyah \\ Fakultas Hukum Universitas Sriwijaya \\ Email: novitaevte@unsri.ac.id, hermansyahtriady@gmail.com \\ Naskah diterima: 04-11-2021, direvisi: 16-11-2021, disetujui: 17-11-2021
}

\begin{abstract}
One type of library collection that must be digitized is the gray literature collection, namely the literature typical of the institution, both published and unpublished. The purpose of this study was to determine the implementation and process of digitization in the Unsri Library and also the processing of gray literature. The method used is descriptive qualitative research method with a comparative approach and data collection techniques are carried out through observation, interviews and literature study. The results of this study indicate that the process of media transfer for Gray Literature manuscripts in the Sriwijaya University Library is the identification and checking (validation) of collections in the database; separation of collections that will be transferred and those that will not (including list generation); media transfer and file processing; upload process to system; and destruction of print collections when they are no longer needed by making a report.
\end{abstract}

\section{ABSTRAK}

Salah satu jenis koleksi perpustakaan yang wajib dilakukan digitalisasi adalah koleksi grey literatur yaitu literatur khas lembaga baik yang diterbitkan maupun yang tidak diterbitkan. Tujuan dari penelitian ini adalah untuk mengetahui pelaksanaan dan proses digitalisasi di Perpustakaan Unsri dan juga pengolahan grey literaturnya. 
Tekhnik yang dipakai adalah metode riset deskriptif kualitatif dengan pendekatan perbandingan dan teknik penghimpunan data dilakukan melalui observasi, wawancara dan studi kepustakaan. Hasil penelitian ini menunjukkan bahwa proses alih media untuk naskah Grey Literature di lingkungan Perpustakaan Universitas Sriwijaya adalah identifikasi dan pengecekan (validasi) koleksi di database; pemisahan koleksi yang akan dialihmediakan dan yang tidak (termasuk pembuatan daftar); proses alihmedia dan olah file; proses unggah ke sistem; dan penghancuran koleksi cetak apabila memang sudah tidak diperlukan dengan dibuatkan berita acaranya.

Keywords: Digitization; Information; Library

\section{PENDAHULUAN}

Transformasi perpustakaan, dari sederhana menuju perpustakaan yang memakai sistem digital tidak dapat ditolak, untuk kepentingan pemustakanya, yaitu mahasiswa beserta dosen dan karyawan dalam mentransfer sains digital dan sains siaga yang selalu tersedia saat diperlukan dengan tiba-tiba. Perpustakaan yang dulunya terdiri dari rak-rak berisi kumpulan buku sudah harus bertransformasi dengan melakukan digitalisasi koleksi.

UU Perpustakaan Nomor 43/2007 mengistilahkan bahwa "perpustakaan merupakan sebuah institusi yang menghimpun pengetahuan tercetak dan terekam, pengelolaannya dengan cara khusus guna melengkapi keperluan intelektualitas pemustaka melalui berbagai cara interaksi pengetahuan".

Dalam hal digitalisasi akses koleksi buku perpustakaan, pemerintah telah melindunginya dengan menetapkan Peraturan Pemerintah Nomor 24 Tahun 2014. Walaupun demikian, upaya alih bentuk pustaka berkaitan dengan ketetapan pemerintah tentang hak cipta. Karena pustaka sebagai karya yang memperoleh proteksi hak cipta menurut Pasal 40 ayat (1) huruf a UU Nomor 28/2014 tentang Hak Cipta (“UUHC”). Kecuali buku, hasil karya yang memperoleh proteksi hak cipta adalah parafrase, takwil,

${ }^{1}$ Bab I Pasal 1 Undang-Undang Nomor 43 Tahun 2007 tentang Perpustakaan 
gubahan, antologi, basis data, komposisi musik, konversi dan karya cipta hasil perubahan. ${ }^{2}$

Salah satu jenis koleksi perpustakaan yang wajib dilakukan digitalisasi adalah koleksi Literatur Kelabu atau Grey Literature, yaitu literatur khas lembaga yang dipublikasikan atau yang tidak. Literatur kelabu adalah semua sumber daya koleksi yang dapat menopang dan bermanfaat sebagai warisan berharga yang perlu dipelihara dan dijaga dengan sebaik-baiknya karena berkaitan langsung dengan institusi dan pengguna (civitas akademika). Yang termasuk dalam literatur kelabu diantaranya adalah sebagai berikut: ${ }^{3}$

a) Koleksi khusus, seperti skripsi, tesis dan disertasi. Koleksi tersebut biasanya digunakan sebagai persyaratan untuk menyelesaikan studi dan disimpan di perpustakaan perguruan tinggi dalam kumpulan karya ilmiah;

b) Laporan riset, laporan kerja, paparan kegiatan dan paparan yang lain yang dihasilkan universitas atau institusi perpustakaan tersebut juga digolongkan dalam koleksi literatur kelabu;

c) Artikel prosiding, kolokium, kongres, call for paper, simposium yang menciptakan karya yang pantas disimpan dalam perpustakaan, yang tentu saja merupakan hasil kegiatan universitas perpustakaan tersebut;

d) Terbitan intern yang dihasilkan universitas atau institusi dari perpustakaan terbitan tersebut, contohnya majalah, bulletin, jurnal dan lain-lain; dan

e) Dokumen lain sebagai jati diri institusi perpustakaan, seperti pamflet, brosur, tata tertib dan sebagainya.

Target yang diinginkan dari kegiatan digitalisasi suatu perpustakaan universitas adalah untuk menambah jumlah, tipe dan subyek sumberdaya informasi elektronik yang dapat diakses secara online dari Universitas itu sendiri maupun Universitas lain, menambah frekuensi kegunaan dan mutu informasi digital dalam aktivitas pendidikan, pengajaran dan riset universitas

${ }^{2}$ Pasal 40 ayat (1) huruf $n$ Undang-Undang Hak Cipta

${ }^{3}$ Departemen Pendidikan \& Kebudayaan RI. Perpustakaan Perguruan Tinggi: buku pedoman. Ed. 3. (Jakarta: Direktorat Jenderal Pendidikan Tinggi. Depdikbud RI, 2004) 5 
tersebut ataupun universitas lain. ${ }^{4}$

Oleh karena itu dengan adanya digitalisasi tersebut maka perpustakaan diharapkan melakukan berbagai pembenahan dan perubahan. Diantaranya adalah perubahan prinsip mengenai pelayanan dan pengembangan koleksi, terutama untuk koleksi grey literaturnya. Jika dahulu pengembangan koleksi dilakukan dengan begitu manual, asal membeli banyak buku karena hanya mengejar kuantitas demi peningkatan statistik jumlah koleksi, tetapi zaman telah berubah. Sekiranya perpustakaan tidak mempunyai data yang diperlukan pemustakanya, perpustakaan dimohon dapat membagi akses kepada pemustaka terhadap informasi yang berada di universitas pemilik informasi tersebut.

Berdasarkan pada latar belakang masalah di atas, dapat dibuat ringkasan masalah sebagai berikut:

1. Bagaimana kebijakan pengembangan koleksi pada Perpustakaan FH UNSRI?

2. Bagaimana strategi yang ditempuh FH UNSRI dalam digitasi koleksi Grey Literatur?

3. Bagaimana kendala yang dihadapai FH UNSRI dalam digitasi koleksi?

\section{TINJAUAN PUSTAKA}

\section{Perpustakaan Perguruan Tinggi}

Perpustakaan Perguruan Tinggi (PPT) adalah perpustakaan yang terdapat pada universitas yang bertugas menyajikan dan menyebarkan informasi untuk mendukung universitas tersebut menggapai misinya yakni Tri Dharma Perguruan Tinggi (pendidikan, penelitian dan pengabdian masyarakat).

Perpustakaan universitas diistilahkan sebagai research library/ perpustakaan penelitian karena diutamakan menjadi tempat dan kegiatan penelitian dimana hal tersebut (penelitian) merupakan salah satu kegiatan

${ }^{4}$ Utomo, Endhar Priyo. Digitalisasi Koleksi Local Content Di Perpustakaan Perguruan Tinggi. Pustaloka: Jurnal Kajian Informasi dan Perpustakaan, Vol. II No. 1, Juni (2019) 
pokok di perguruan tinggi.

Searah dengan kemajuan dan pertumbuhan sains, teknologi, komunikasi dan budaya serta penambahan keperluan pemustaka sehingga peran Perpustakaan Universitas juga diperluas dengan lebih spesifik:

1) Studying Center, perpustakaan sebagai tempat belajar, dapat dipakai untuk menunjang belajar, yaitu memperoleh informasi sesuai dengan keperluan dalam strata pendidikan;

2) Learning Center, berperan menjadi pusat pembelajaran (tidak hanya belajar) yaitu eksistensi perpustakaan difungsikan sebagai tempat untuk membantu proses pembelajaran. (UU Nomor 2 Tahun 1989 Ps. 35 "Perpustakaan harus ada di setiap satuan pendidikan yang merupakan sumber belajar")

3) Research Center, perpustakaan dapat dimanfaatkan sebagai pusat informasi untuk memperoleh bahan atau informasi untuk membantu pelaksanaan riset;

4) Information Resources Center, perpustakaan berperan sebagai sentral informasi;

5) Preservation of Knowledge Center, perpustakaan sebagai pusat pelestari ilmu pengetahuan sebagai cipta karya dan tulisan bangsa yang disimpan baik sebagai koleksi deposit, local content atau grey literature;

6) Dissemination of Information Center, fungsi perpustakaan tidak hanya menghimpun, mengolah, menyajikan atau melestarikan namun juga berfungsi dalam menyiarkan atau memasarkan informasi; dan

7) Dissemination of Knowledge Center, bahwa disamping menyiarkan informasi perpustakaan juga bertugas untuk menyiarkan pengetahuan (terutama untuk pengetahuan baru).

\section{Koleksi Digital}

Naskah elektronik bisa bersumber dari 2 (dua) tempat, pertama, asli dari arsip komputer (born digital), yaitu arsip yang diketik dan disimpan di komputer. Kedua, berasal dari dokumen tercetak (printed document), 
yaitu dokumen tersebut bisa berasal dari hasil ketikan dari mesin ketik konvensional (non-komputer), atau hasil cetakan dari percetakan komersial. Terhadap berkas tersebut dialih bentukkan melalui pemindaian (scan), metode inilah yang disebut dengan digitalisasi.

Digitalisasi perpustakaan dilakukan guna menjawab kepentingan pemustaka tentang informasi yang semakin rumit, baik mutu maupun jumlahnya. Digitalisasi informasi perpustakaan juga dilakukan dalam rangka menumbuhkan kinerja dan perpustakaan itu sendiri, sehingga perpustakaan dapat mempunyai daya saing dengan perpustakaan lainnya, dengan menekankan segi kepraktisan, kemudahan, kecepatan dan keakuratan dalam pelayanannya.

Beberapa keuntungan alih bentuk untuk perpustakaan yang disampaikan oleh para ahli sebagaimana dikutip dalam Azizah, 2012 sebagai berikut: ${ }^{5}$ peningkatan koleksi yang lebih cepat dengan mutu yang lebih baik; dapat mempercepat akses sehingga data yang diperlukan bisa secepat mungkin dikuasai dan dimanfaatkan pemustaka; pasti mampu dihubungkan lebih cepat bila sistem digitalisasi dipakai di lingkungan universitas dengan jejaring, baik jaringan LAN maupun internet atau apapun itu yang berkorelasi untuk meperoleh sambungan sistem digitalisasi tersebut; dan pemustaka dapat mengakses bentuk format tercetak dan dalam bentuk format suara, gambar, video dan masih banyak lagi lainnya.

Pemustaka semakin banyak berharap terhadap kreativitas, efesiensi dan efektifitas dalam mengakses semua layanan perpustakaan melalui jaringan, termasuk katalog, permohonan dan penyampaian dokumen, serta layanan lainnya. Dengan jaringan membuat lebih banyak orang yang bertugas pada work station dengan memanfaatkan komputer personal multimedia, yang terhubung dengan jejaring komputer lainnya, baik domestik maupun global, yang dapat memproduksi bentuk dokumen tercetak maupun elektronik, serta terbitan lembaga dari berbagai sumber, baik intranet maupun internet. Masyarakat dapat lebih lancar dalam memperoleh bahan

${ }^{5}$ Azizah, Lailan. Penerapan Digitalisasi Untuk Perpustakaan. Jurnal Iqra', Vol. 06 No. 02, Oktober (2012): 60-61 
dari banyak sumber secara cepat, tepat, dan akurat. Karena kesuksesan sebuah perpustakaan bukan dilihat dari seberapa banyak jumlah koleksi yang dimilikinya, akan tetapi bisa dilihat dari seberapa besar manfaat yang diperoleh pengguna tersebut.

Menurut Pendit ${ }^{6}$, dengan digitalisasi, perpustakaan mampu mendokumentasikan beribu-ribu bahkan jutaan karya tulis maupun kreasi seni tanpa celah ruang dan waktu. Dengan alih bentuk koleksi literatur yang mengubah koleksi tercetak (konvensional) ke koleksi digital, maka suatu perpustakaan mendapatkan keuntungan yaitu: menyingkat area penyimpanan; dapat disimpan di website (online) dan dapat dimanfaatkan oleh siapapun dimanapun dan kapanpun. ${ }^{7}$

Keuntungan lainnya yaitu: semakin sederhana mengemas informasi; dapat dimanfaatkan oleh siapapun dengan serentak; tanpa celah ruang dan waktu; dan sistem elektronik lebih sederhana dalam urusan perencanaan dan dapat dimanfaatkan dengan lebih kencang, cermat dan akurat.

\section{METODE}

Riset dalam tulisan ini memakai teknik penelitian deskriptif kualitatif dengan pendekatan perbandingan karena peneliti memang ingin menggambarkan objek penelitian berdasarkan fakta yang tampak atau secara apa adanya sehingga dapat lebih mudah dipahami dan disimpulkan.

Dalam penelitian ini, objek penelitiannya adalah digitalisasi dan pemeliharaan bahan pustaka. Fokus penelitian adalah tolok ukur pemilihan bentuk literatur yang dialihbentukkan.

Teknik pengumpulan data yang digunakan adalah sebagai berikut:

\section{Observasi}

Merupakan aktivitas melaksanakan pengamatan secara langsung terhadap sasaran penelitian. Observasi dapat menjadi komparasi apakah yang

${ }^{6}$ Pendit, Putu L. Perpustakaan Digital: Perspektif Perpustakaan Perguruan Tinggi Indonesia (Jakarta: Sagung Seto, 2007) 241-242

${ }^{7}$ Supriyanto, Wahyu \& Ahmad Muhsin, Teknologi Informasi Perpustakaan (Yogyakarta: Kanisius, 2008) 2 
disampaikan oleh responden sesuai dengan apa yang dilakukannya, teknik observasi juga dapat mengenali tingkah laku, respon dan sebagainya dari seseorang yang mungkin berfikir untuk tidak menyampaikan fakta karena merasa hal itu tidak berguna atau tidak berkaitan. Pada observasi ini, yang menjadi objek adalah kegiatan yang langsung mengamati proses digitasi pada pustakawan FH dan Perpustakaan UNSRI.

2. Wawancara

Penulis melaksanakan interviu dengan siapapun yang turut serta dalam aktivitas alih bentuk literatur, baik pembuat kebijakan atau pengambil pedoman standar teknis maupun pelaksana teknis di lapangan. Pada penelitian ini, yang menjadi objek interview atau terwawancara adalah pustakawan yang terlibat dalam digitasi koleksi pada perpustakaan $\mathrm{FH}$ dan perpustakaan UNSRI.

3. Studi Kepustakaan (library research)

Penulis melaksanakan telaah pendalaman literatur guna menyatukan bahan pustaka yang berkenaan dengan alih bentuk literatur. Melalui studi literatur ini, penulis ingin memperoleh referensi yang berguna sebagai petunjuk atau panduan yang mampu membantu teori-teori atau menyelesaikan persoalan riset.

Analisis data riset ini terdiri dari beberapa alur kegiatan yang dilakukan secara bersama dan menggunakan metode reduksi data yaitu menelaah data dari berbagai sumber, dimulai dari pencatatan data di lapangan, reduksi data, display data dilanjutkan dengan membuat kesimpulan dari data tersebut. Hal tersebut dikemukakan oleh Miles dan Huberman yang bertujuan untuk mendapatkan dan menciptakan persepsi terhadap alur kegiatan dan memperoleh data secara teliti, cermat dan komprehensif. 


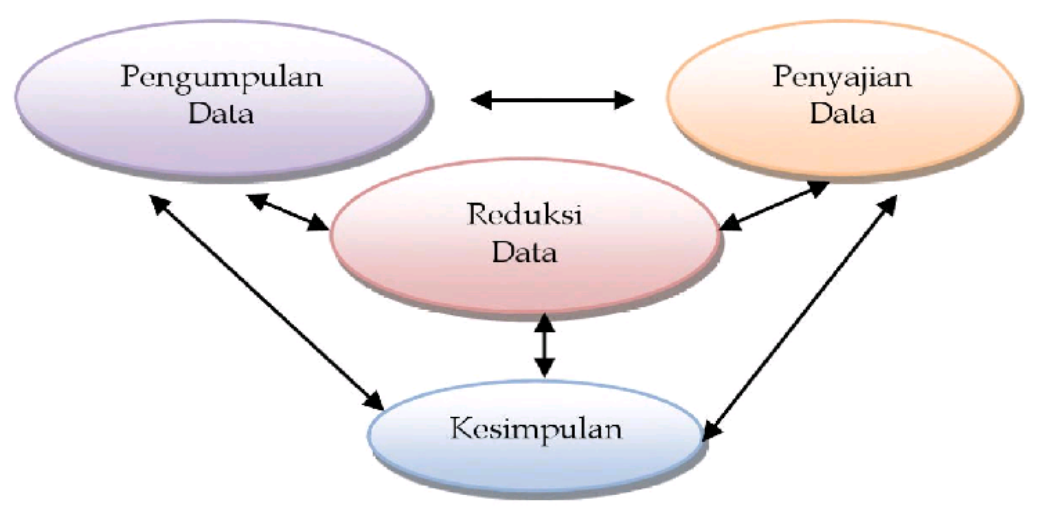

\section{Gambar Skema Model Analisis Data Interaktif (Model Milles dan Huberman)}

Skema ini menunjukkan bahwa untuk memudahkan penyajian data, maka beberapa langkah-langkah dalam analisis data yang dipakai dalam penelitian ini, terbagi dalam kegiatan penghimpunan data (data collection), reduksi data (data reduction), penyajian data (data display) dan penarikan kesimpulan (conclusions).

\section{HASIL DAN PEMBAHASAN}

Kebijakan pengembangan koleksi pada Perpustakaan Fakultas Hukum Unsri

Pengembangan koleksi merupakan aktivitas yang dimaksudkan untuk menyatukan kepentingan pemustaka dengan rekaman informasi dalam area perpustakaan. Pada proses ini menegaskan bahwa keperluan data pemustaka dapat terwujud secara on time dan tepat sasaran dengan menggunakan informasi yang dikumpulkan oleh perpustakaan. Informasi tersebut harus dikembangkan dengan baik sesuai dengan keadaan perpustakaan dan masyarakat yang dilayani ${ }^{8}$.

${ }^{8}$ Herlina. Manajemen Perpustakaan Pendekatan Teori dan Praktik (Palembang: Grafika Telindo Press, 2009) 59 
Tujuan dilakukan pengembangan koleksi tersebut adalah (a) untuk memperbanyak jumlah koleksi, yang bisa diperoleh melalui pembelian, hadiah/hibah, tukar menukar maupun kerjasama antar perpustakaan; (b) meningkatkan jenis bacaan, baik karya cetak, non cetak maupun karya rekam; (c) untuk meningkatkan mutu dan kualitas koleksi yang disesuaikan dengan kebutuhan masyarakat pemustaka.

Bagi perpustakaan Fakultas Hukum Unsri yang memiliki 4 (empat) tenaga perpustakaan terdiri dari 2 pustakawan dan 2 administrasi dibawah pengawasan langsung Wakil Dekan I bidang akademik, kebijakan pengembangan koleksi diusulkan oleh pustakawan sebagai masukan bagi pimpinan untuk dapat ditindaklanjuti penerapannya dan juga dapat digunakan sebagai masukan untuk merevisi kebijakan yang telah ada sebelumnya.

Kegiatan pengembangan koleksi dilakukan untuk untuk mengadakan literatur baru di perpustakaan bersumber pada hasil pemilihan dan penilaian literatur serta usulan pemustaka untuk membantu penelitian yang dilakukan. Pengembangan koleksi meliputi kegiatan memilih dan mengadakan bahan perpustakaan sesuai dengan kebijakan yang ditentukan. Yang perlu dipikirkan kembali dalam merumuskan kebijakan pengembangan koleksi, antara lain sebagai berikut: a) Kepentingan pemustaka; b) Tipe literatur; c) Kriteria koleksi; d) Jumlah eksemplar; dan e) Bahasa.

Pihak yang berperan dalam menetapkan kebijakan pengadaan dan pengembangan koleksi di Perpustakaan Fakultas Hukum Unsri yaitu Dekan dan para wakil dekan dengan usulan pustakawan setelah melakukan upaya jemput bola ke pemustaka, dalam hal ini para dosen dan mahasiswa di lingkungan Fakultas Hukum Unsri. Rincian prosedur standar operasional pengadaan buku di Perpustakaan Fakultas Hukum adalah sebagai berikut: 


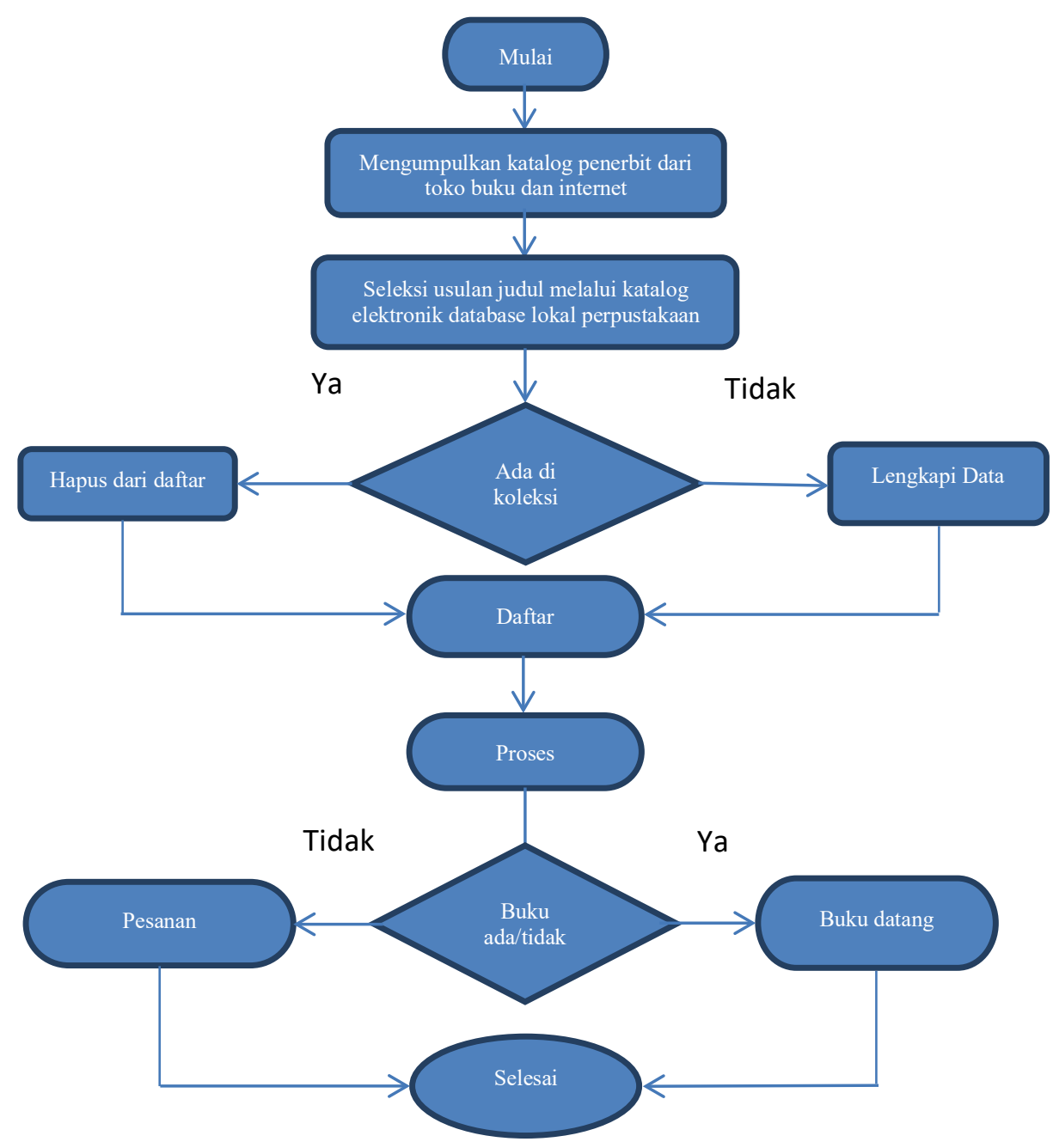

\section{Gambar Prosedur Operasional Pengadaan Buku FH Unsri}

\section{Strategi yang ditempuh FH UNSRI dalam digitasi koleksi Grey Literatur}

Suatu perpustakaan pasti mempunyai berbagai macam koleksi. Salah satunya adalah grey literature/literatur kelabu. Grey literature merupakan sumber informasi penting. Walaupun tidak selalu bersifat ilmiah, namun grey literature seringkali dihasilkan oleh peneliti dan praktisi di bidangnya. 
Koleksi tersebut bersifat unpublished sehingga penggunaannya pun juga sekedarnya, tidak dapat dipinjam keluar dari perpustakaan dan jumlahnya hanya 1 (satu) eksemplar per judul.

Pada UPT Perpustakaan Universitas Sriwijaya pengolahan dari bentuk konvensional ke digital hanya dilakukan untuk koleksi-koleksi lama yang belum ada versi digitalnya. Sejak \pm tahun 2018 perpustakaan tidak lagi menerima koleksi grey literature tersebut dalam bentuk tercetak tetapi melalui unggah mandiri dalam bentuk pdf ke https://repository.unsri.ac.id. .

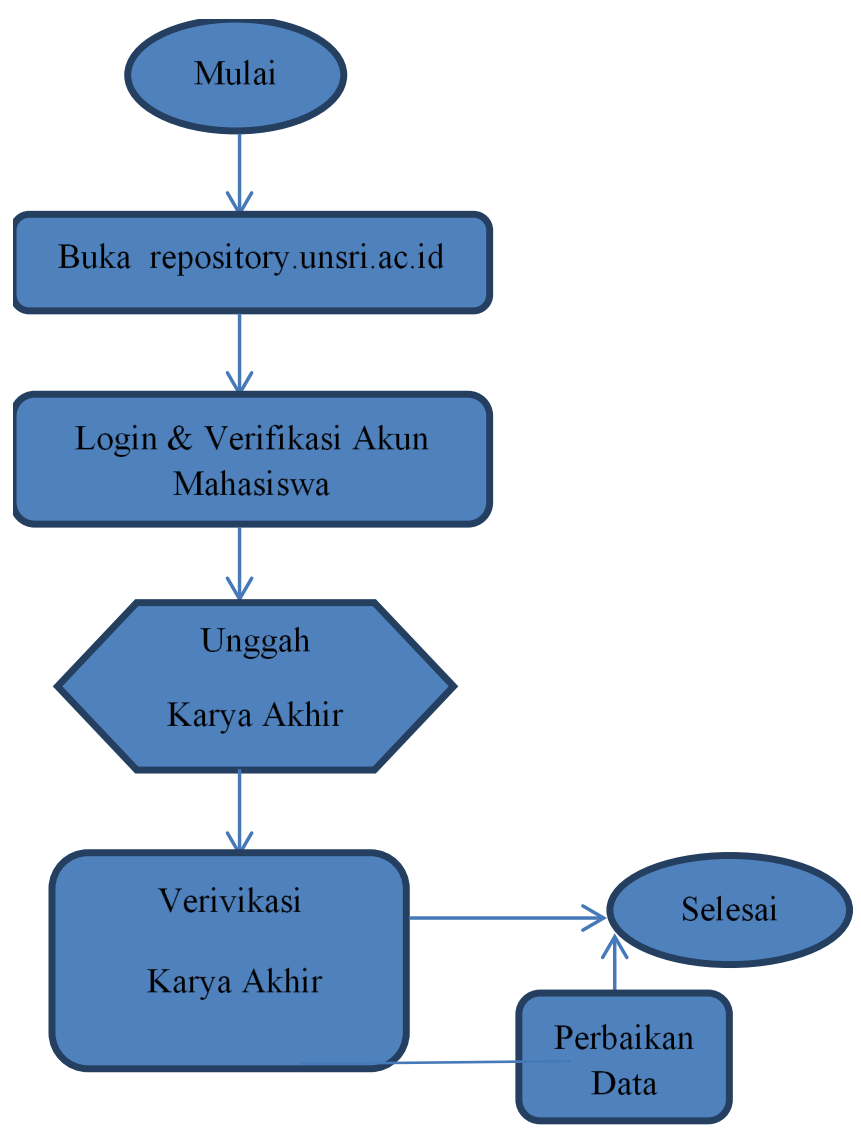

Gambar Unggah Mandiri Perpustakaan Unsri 
Sistem unggah mandiri mulai diberlakukan dan menjadi persyaratan untuk mengikuti wisuda, pegawai perpustakaan melakukan verivikasi data sekiranya format yang di-unggah sudah sesuai prosedur. Unggah mandiri tersebut untuk mempermudah mahasiswa mempublikasikan karya ilmiahnya menggunakan sistem repositori Universitas. Disisi lain, manfaat dan keuntungan bagi Universitas tentu saja bukan dalam bentuk uang, tetapi lebih kepada pamor. Karena semakin banyak penulis mengutip karya ilmiah Universitas tertentu, maka Universitas tersebut semakin unggul sebagai Universitas yang memiliki pamor dalam bidang ilmu tertentu. Pamor yang bagus dapat menjadikan prestasi Universitas tersebut semakin bertambah dan akan dipertimbangkan oleh publik dan para ilmuwan. ${ }^{9}$

Fasilitas yang perlu disiapkan dalam proses digitalisasi untuk koleksi yang belum ada versi digitalnya adalah 1 . Fasilitas untuk mengakses koleksi yakni berupa aplikasi untuk akses koleksi (portal penelusuran, portal unggah, aplikasi single sign on), komputer untuk akses staf dan mahasiswa, peralatan alih media (digitalisasi) seperti scanner dan kamera digital; 2. Jaringan internet atau komputer yang memadai dan bandwidth yang cukup.

Proses alih media untuk naskah Grey Literature di lingkungan Perpustakan Universitas Sriwijaya adalah sebagai berikut:

- Identifikasi dan pengecekan (validasi) koleksi di database;

- Pemisahan koleksi yang akan dialihmediakan dan yang tidak (termasuk pembuatan daftar);

- Proses alihmedia dan olah file;

- Proses unggah ke sistem; dan

- Penghancuran koleksi cetak apabila memang sudah tidak diperlukan dengan dibuatkan berita acaranya.

Sementara itu, untuk perpustakaan Fakultas Hukum Universitas Sriwijaya masih dilakukan secara manual. Koleksi Grey Literatur seperti

${ }^{9}$ Rifauddin, Machsun \& Arfin Nurma Halida, Persepsi Mahasiswa Terhadap Sistem Unggah Mandiri dan Akses ETD Repositori di Perpustakaan UGM Yogyakarta. Pustabiblia: Journal of Library and Information Science, Vol. 2, Number 2, December (2018): 201-202 
skripsi, tesis dan disertasi mahasiswa hanya diserahkan ke bagian perpustakaan dengan mengisi form penyerahan sebagai tanda terima, kemudian petugas di perpustakaan melakukan registrasi, nomor klassifikasi dan input data ke dalam web perpustakaan ruangbaca.fh.unsri.ac.id. Perpustakaan Fakultas Hukum hanya memasukkan abstrak dan identitas lengkap karya akhir tersebut ke dalam web ruangbaca.fh.unsri.ac.id, seandainya ada pemustaka yang membutuhkan file tersebut dapat menghubungi perpustakaan Universitas Sriwijaya dengan mengisi form registrasi repository Perpustakaan yang dapat diunduh melalui https://digilib.unsri.ac.id.

Penelitian mengenai digitalisasi tersebut sebelumnya sudah pernah dilakukan sebelumnya oleh Hendarsyah tahun 2013 dengan judul Digitalisasi Dan Sistem Otomasi Perpustakaan STIE Syari ah Bengkalis. Fokus penelitian Hendarsyah adalah lebih kepada akses koleksi secara digital pada pengguna perpustakaan di lingkungan STIE Syaria ah Bengkalis. Selain itu, juga pernah ditulis sebagai laporan tugas akhir oleh Salbiah pada tahun 2017 dengan judul Analisis Kebijakan Digitalisasi Koleksi Skripsi dan Kaitannya Dengan Kemudahan Akses Informasi Mahasiswa di UPT Perpustakaan UIN Ar-Raniry. Tujuan observasi tersebut untuk memahami aturan alih bentuk tugas akhir menggunakan fasilitas akses informasi mahasiswa.

\section{Kendala yang dihadapi pada proses digitasi Grey Literatur pada Perpustakaaan FH UNSRI}

Proses alih media di Perpustakaan Fakultas Hukum Universitas Sriwijaya untuk koleksi grey literature tergolong sangat jarang dilakukan dikarenakan ada beberapa kendala yang sangat riskan untuk melakukan kegiatan tersebut, diantaranya (a) masalah Sumber Daya Manusia, karena tidak semua staf mempunyai kemampuan beradaptasi dengan kemajuan teknologi seperti sekarang ini; (b) Dana, sudah dapat dipastikan diperlukan dana yang tidak sedikit. Kurangnya dana yang tersalurkan untuk kegiatan alih media, padahal sebagai tahap awal dipastikan kebutuhan dana untuk persiapan infrastruktur, seperti komputer, scanner, jaringan listrik, pelatihan staf yang akan ditugaskan pada unit tersebut; (c) Kepemimpinan, sangat 
memerlukan komitmen dan dukungan dikarenakan hal tersebut akan berimbas pada kebijakan selanjutnya dan dapat mempengaruhi bawahannya; (d) Konsistensi, dapat menjadi kendala apabila ada pegawai dan pimpinan yang tidak mau bertanggungjawab dan berkomitmen untuk mengikuti perkembangan ke arah yang lebih modern; (e) Komunikasi, sudah seharusnya untuk melakukan komunikasi yang efektif dan dua arah supaya terjadi diskusi yang menyenangkan antara staf dan pimpinan sebagai eksekutor kegiatan tersebut.

Selain hal tersebut diatas, masih terjadi kendala kurangnya sosialisasi dari UPT Perpustakaan Unsri ke fakultas-fakultas sehingga tidak semua staf perpustakaan fakultas memahaminya dan juga tidak semua mahasiswa dapat mengupload tugas akhirnya secara mandiri pada repository yang sudah disediakan.

\section{KESIMPULAN}

Simpulan pada penelitian ini ditemukan bahwa pihak yang berperan dalam menetapkan kebijakan pengadaan dan pengembangan koleksi di Perpustakaan Fakultas Hukum Unsri adalah Dekan dan para wakil dekan dengan usulan pustakawan setelah melakukan upaya jemput bola ke pemustaka, dalam hal ini para dosen dan mahasiswa di lingkungan Fakultas Hukum Unsri. Kegiatan pengembangan koleksi tersebut dilakukan untuk untuk mengadakan koleksi yang aktual di perpustakaan berlandaskan hasil pemilihan dan penilaian literatur serta usulan pemustaka untuk membantu penelitian mereka.

Pada UPT Perpustakaan Universitas Sriwijaya pengolahan dari bentuk konvensional ke digital hanya dilakukan untuk koleksi-koleksi lama yang belum ada versi digitalnya. Proses alih media untuk naskah Grey Literature di lingkungan Perpustakaan Universitas Sriwijaya adalah sebagai berikut: Identifikasi dan pengecekan (validasi) koleksi di database; Pemisahan koleksi yang akan dialihmediakan dan yang tidak (termasuk pembuatan daftar); Proses alihmedia dan olah file; Proses unggah ke sistem; dan Penghancuran koleksi cetak apabila memang sudah tidak diperlukan 
dengan dibuatkan berita acaranya. Sementara itu di perpustakaan Fakultas Hukum Universitas Sriwijaya masih dilakukan secara manual. Koleksi Grey Literatur seperti skripsi, tesis dan disertasi mahasiswa hanya diserahkan ke bagian perpustakaan dengan mengisi form penyerahan sebagai tanda terima, kemudian petugas di perpustakaan melakukan registrasi, nomor klassifikasi dan input data ke dalam web perpustakaan ruangbaca.fh.unsri. ac.id. Perpustakaan Fakultas Hukum hanya memasukkan abstrak dan identitas lengkap karya akhir tersebut ke dalam web ruangbaca.fh.unsri. ac.id, seandainya ada pemustaka yang membutuhkan file tersebut dapat menghubungi perpustakaan Universitas Sriwijaya dengan mengisi form registrasi repository Perpustakaan yang dapat diunduh melalui https://digilib. unsri.ac.id. Adapun beberapa kendala yang dihadapi pada proses digitasi Grey Literatur pada Perpustakaaan FH UNSRI yang terutama adalah masalah sumber daya manusia, dana, kepemimpinan, konsistensi dan komunikasi.

Dari hasil penelitian ini masukan yang ingin disampaikan yaitu masih perlunya dukungan kebijakan pengelolaan koleksi grey literatur di lingkungan Universitas Sriwijaya pada umumnya dan khususnya Fakultas Hukum, peningkatan pemberdayaan koleksi digital khususnya grey literatur dan juga penambahan sumberdaya manusia untuk khusus bagian alih media.

\section{DAFTAR PUSTAKA}

Alifah Rahmawati, Nurul. 2017. Penggunaan Teknologi Informasi dalam Pelayanan Sumber Informasi di Perpustakaan. Libria, Vol. 9 No. 2, Desember

Anonim. 2018. Internet of Things, Big Data dan Artificial Intelligence. Sb. https://apic.id/blog/2018/03/21/internet-of-things-big-data-danartificial-intelligence/, diakses 14 Desember 2019, pk. 11.19 wib

Azizah, Lailan. 2012. Penerapan Digitalisasi Untuk Perpustakaan. Jurnal Iqra ', Vol. 06 No. 02, Oktober

Departemen Pendidikan \& Kebudayaan RI. 2004. Perpustakaan Perguruan Tinggi: buku pedoman. Ed. 3. Jakarta: Direktorat Jenderal Pendidikan 
Tinggi. Depdikbud RI

Fajar Prianto, Ida. 2015. Kesiapan Pustakawan Membangun Repository Akses Terbuka (open access). Artikel Seminar UGM, 27 September . Yogyakarta

Fatmawati, Endang. 2017. Revolusi budaya digitalisasi informasi: dampaknya bagi pustakawan dalam mengelola pengetahuan. Jurnal Iqra ' Volume 11 No. 02, Oktober: 2

Hartono. 2017. Strategi Pengembangan Perpustakaan Digital Dalam Membangun Aksesibilitas Informasi: sebuah kajian teoritis pada Perpustakaan Perguruan Tinggi Islam di Indonesia. Jurnal Perpustakaan, Vol. 8 No. 1

Hartono. 2019. Manajemen Perpustakaan Elektronik (E-Library) Konsep Dasar, Dinamika dan Sustainable di Era Digital. Yogyakarta: Gava Media

Marajari, M. Rinaldi. Peran Perpustakaan Memanfaatkan Library 4.0 Pelayanan Berbasis Digital. 2019. Sb. https://perpustakaan.uma. ac.id/library-4-0-peran-perpustakaan-memaksimalkan-pelayananberbasis-digitalisasi/, diakses 14 Desember 2019 pk. 11.54 wib

Moleong, Lexy J. 2010. Metode Penelitian Kualitatif. Bandung: PT Rosdakarya Mulyana, Deddy. 2010. Metodologi Penelitian Kualitatif: Paradigma Baru Ilmu Komunikasi dan Ilmu Sosial Lainnya. Bandung: Remaja Rosdakarya Pasal 20 Peraturan Pemerintah Nomor 24 Tahun 2014 tentang Pelaksanaan Undang-Undang Nomor 43 Tahun 43 Tahun 2007 tentang Perpustakaan

Pendit, Putu L. 2007. Perpustakaan Digital: Perspektif Perpustakaan Perguruan Tinggi Indonesia. Jakarta: Sagung Seto, 2007

Rahayu, Lisda. 2011. Pelayanan Bahan Pustaka. Jakarta: Universitas Terbuka Riadi, Muchlisin. 2019. Kecerdasan Buatan (Artificial Intelligence). Sb. https:// www.kajianpustaka.com/2019/03/kecerdasan-buatan-artificialintelligence.html, diakses 16 Desember 2019, pk. 10.35 wib

Rifauddin, Machsun \& Arfin Nurma Halida. 2018. Persepsi Mahasiswa 
Terhadap Sistem Unggah Mandiri dan Akses ETD Repositori di

Perpustakaan UGM Yogyakarta. Pustabiblia: Journal of Library and Information Science, Vol. 2, Number 2, December

Riyana, Cepi. 2011. ICT Dalam Perpustakaan. EduLib, Vol. 1, November

Ruldeviyani, Yova \& Yudho Giri Sucahyo. 2007. "Infrastruktur Perpustakaan

Digital” dalam Perpustakaan Digital: Perspektif Perpustakaan Perguruan Tinggi Indonesia. Jakarta: Universitas Indonesia

Sanjaya, F. Ridwan. 2018. Library 4.0 untuk Perpustakaan Masa Depan. Sb. https://news.unika.ac.id/2018/05/library-4-0-untuk-perpustakaanmasa-depan/, diakses 14 Desember 2019, pk. 11.13 wib

Setiawan, Wawan. 2017. Era Digital dan Tantangannya. Seminar Nasional Pendidikan, sb. https://core.ac.uk/download/pdf/87779963.pdf. , diakses 2 Desember 2019, pk. 15.07 wib

Sugiyono. 2012. Metode Penelitian KuantitatifKualitatifDan R\&D. Bandung: Alfabeta

Suminarsih, Eka Meifrina. 2010 Pengembangan Perpustakan Dijital Untuk Meningkatkan Pemanfaatan Grey Literature Di Indonesia. Media Pustakawan, Vol. 17 Nomor 3-Juni, sb. https://www.perpusnas.go.id/ magazine-detail.php?lang=id\&id=8252, diakses 13 Desember 2019, pk. 13.12 wib

Supriyanto, Wahyu \& Ahmad Muhsin. 2008. Teknologi Informasi. Yogyakarta: Kanisius

Susanto, Setyo Edy. 2010. Desain Dan Standar Perpustakaan Digital. Makalah Workshop Pengembangan Design dan Standarisasi Database Perpustakaan Digital. Perpustakaan Republik Indonesia. Ardi Koesoema, Bogor, 8 November 2010. Jurnal Pustakawan Indonesia, Vol. 10 No. 2

Teguh Dwi Putranto, Muhammad. 2015. Proses Digitalisasi Koleksi Deposit Di UPT Perpustakaan Daerah Provinsi Jawa Tengah. Jurnal Ilmu Perpustakaan, Vol. 4 No. 3, Juli

Undang-Undang Nomor 43 Tahun 2007 tentang Perpustakaan 
Undang-Undang Nomor 28 Tahun 2014 tentang Hak Cipta (Undang-Undang Hak Cipta)

Utomo, Endhar Priyo. 2019. Digitalisasi Koleksi Local Content Di Perpustakaan Perguruan Tinggi. Pustakaloka: Jurnal Kajian Informasi dan Perpustakaan, Vol. 11 No. 1, Juni

Yuventia, Yuniwati. 2012. Standarisasi Perpustakaan Perguruan Tinggi. Sb. http://digilib.undip.ac.id/, diakses 26 November 2019, pk. 09.37 
Novita Vitriana, Triady Hermansyah 